\title{
Demographic Determinants of Miraa Chewing Among the Youth in Central Division of Wajir East Sub County, Kenya
}

\author{
Abdikadir Sheikh Abdisalan \\ asabdisalan@yahoo.com \\ Prof. Kibet Ngetich., Ph D \\ kngetich@egerton.ac.ke/k_ngetich@yahoo.com \\ Dr. Hadija Murenga, PhD \\ matuli15@yahoo.com,matuli115@gmail.com,fass@egerton.ac.ke \\ Faculty of Arts and Social Sciences, Egerton University, Njoro, Kenya
}

\begin{abstract}
Kenya is a major producer and exporter of miraa. Locally, it is predominantly consumed in Wajir and the other adjacent counties in the northern parts of country. Some of the socio-economic and health problems affecting the youth from this part of the country have been linked to excessive chewing/consumption of miraa. Although literature on miraa is fairly extensive, little has been done to identify the determinants of its use. This study was conducted to establish the demographic determinants of miraa chewing among the youth in Central Division of Wajir East Sub County. A sample of 119 youth and key informants were interviewed. The study established that $42.9 \%$ of the youth from the area have chewed miraa at least once in their lifetime. The demographic determinants of miraa chewing among the youth were age, gender and level of education, ( $p$-value $<0.05)$. The main reasons reported for mira chewing were 'to relieve stress', 'to pass/kill time' and to 'work hard'. The findings of this study will to contribute to formulation of appropriate preventive strategies for managing challenges of miraa chewing among the youth and also enrich existing body of knowledge on miraa use.
\end{abstract}

Keywords: Miraa Demographic Determinants Youth Wajir Kenya

\section{INTRODUCTION}

Miraa (Catha edulis) is a plant substance of abuse that is widely used in East and horn of Africa, and parts of Arabian Peninsula for its stimulating effects. The common name of the substance in Kenya is miraa. It is also known by other names such as khat, chat, gomba, and veve.

Miraa is among the four or five leading drugs of abuse in East Africa and it is mainly used by the youth [1]. It produces dependence, tolerance and mild withdrawal symptoms. It is marked with socioeconomic problems such as family instability, economic strain and prolonged absenteeism of the father from the family, malnutrition and poor education performance [2]. Miraa contains a psychoactive substance, cathinone, which produces central nervous system stimulation analogous to amphetamine and it is believed that miraa chewing has a negative impact on the physical and mental health of individuals as well as the socioeconomic condition of the family and the society at large [3]. Despite miraa being a major source of income to miraa producing countries, it also impacts negatively on food security because it makes farmers abandon cultivation of more essential crops like cereals $[4,5]$. This situation contributes to increased malnutrition and related diseases among the population [6].

Upon chewing miraa, one experience unusual feeling of excitement and alertness, talking too much, lose of concentration on simple tasks or even forgets simple facts and also causes chronic constipation since it causes dehydration [7]. Apart from the habitual use of miraa for pleasure it is widely misconceived that it can improve student academic performance, can keep one awake and can also provide extra vigor and energy [8]. Consumption of miraa by student youth is of particular concern since it interferes with normal learning process thus leading to poor academic performance [9]. Miraa use increases the risk of the youth in indulging in unsafe sexual pattern [10]. Miraa chewing also leads to other numerous adverse social, psychological and medical effects [11, 12, and 13]. 
Baseline survey carried out by National Coordinating Agency against Drug Abuse (NACADA) on drugs and substance abuse amongst the youth in Kenya indicate miraa as one of the major substances of abuse [14]. Numerous studies have also revealed that miraa is used by both male and female in Kenya and several other countries [15, 16, 17, 18, 19, 20, and 21].

Although, miraa in Kenya is mainly grown in Meru and Embu region, majority of its local consumers are mostly in Wajir and other neighboring counties in north eastern and upper eastern province [22]. Miraa chewing has been hindering development and destroying livelihood in these areas [23]. Miraa consumption among the youth in Wajir has contributed to increase in mental diseases, increased impotency, high divorce rates, increased rape cases, increased drop out from schools, poor academic performance, increased domestic violence, decreased economic productivity and increased poverty [24].

The study was conducted in Central Division of Wajir East Sub County located in north eastern region of Kenya. The objective of the study was to establish the demographic determinants of miraa use among the youth. The study targeted youth who fall in the age bracket 18-35 years. Other persons who were considered to hold crucial and relevant information about the study (key informants) were also interviewed.

\section{MATERIALS AND MeTHODS}

\subsection{Research Design \& Sampling Procedure}

The study adopted descriptive social survey research design, which combines both quantitative and qualitative approaches in collection of information from the study sample.

A representative sample of 119 youth was interviewed from households in Central Division of Wajir East Sub County through cluster, proportionate to size, systematic and simple random sampling techniques. The households were drawn from the national sample frame operated by the Kenya National Bureau of Statistics known as NASSEP IV (National Sample Survey and Evaluation Programme). Central Division is divided into seven clusters . Households were drawn from all of the clusters in proportion to the size of the cluster. Systematic sampling procedure was used in selection of households in each cluster. At household level a youth (aged 18-35 years) who was available at the time of the study was interviewed. In case there were more than one youth in a given household, simple random sampling technique was applied in selecting of one them. A household in which an eligible respondent was not available or no one was in the household at the time of the survey was replaced with next household but that household was included in the skip value of the systematic sampling, hence this ensured response rate of $100 \%$.

Seven (7) key informants were also interviewed and were selected using purposive sampling techniques. The key informants were drawn from individuals who had information relevant to the study by virtue of their position in the society. One (1) key informant was drawn from each of the following categories using extreme case purposive sampling techniques: chiefs, councilors, religious leaders, representatives of youth organizations and officials from the ministry of youth affairs, public health and education.

\subsection{Data Collection Tools \& Methods}

Structured interview method was utilized in collection of quantitative data from a sample of 119 youth. The data collection instrument that was used for this purpose was an interview schedule. To ensure validity and reliability of the data collection instrument, the interview schedule was pre-tested with a small sample of youth from the neighbouring Tarbaj division in Wajir East Sub County. Tarbaj division was selected for the pilot study due to existence of miraa chewing in the area and also its youth population has socio-demographic characteristics similar to that of the study population. However the sample from the pre- test was not included in the actual study. Semi -structured interview method, using key informants' interview guide was used to collect qualitative information from the selected key informants.

The main advantage of using the interview method was its suitability for illiterate respondents, high response rate and allowed the researcher to clarify to the respondents what was not clear, and it enabled the collection of detailed data. This was found to be particularly appropriate for a study of this nature. 


\subsection{Data Analysis}

A statistical tool in SPSS for Windows Version 18.0 was applied in the analysis and presentation of the quantitative data. Descriptive statistical tools such as means and frequencies were used to organize, summarize and show patterns in the raw data collected which allowed simpler interpretation of the data. Chi-square was used to measures the association between the dependent and independent variables. Graphs were utilized in data presentation. The raw qualitative data that was collected from the Key Informants was analyzed by thematic content analysis techniques. The recorded qualitative information was perused to identify, highlight and summarize most frequent responses that were relevant to the study objectives, with aim of constructing direction of the flow of the arguments and ideas. The purpose of the qualitative information was complementary by providing in-depth, explanations, details and meanings to the findings of the quantitative survey research.

\section{RESULTS AND DISCUSSION}

A total of 119 youth were interviewed. Majority of the respondents were male (64.7\%) and female constituted $35.3 \%$. Table 1 presents data on chewing of miraa by gender. Forty three percent (43\%) admitted that they have chewed miraa at least once in their lifetime. Majority of the male respondents interviewed (52\%) admitted that they have chewed miraa compared with the female respondents where 26.2\% reported that they have chewed miraa. A similar study in Agaro region, Ethiopia established that $64 \%$ of the youth chew miraa and the prevalence of miraa chewing was high among male compared to female [25]. The prevalence of miraa chewing in Agaro region of Ethiopia is higher than that of this study, possibly because miraa is cultivated in that region of Ethiopia, hence youth would have easy access to miraa. Another study in Ethiopia also reported higher prevalence of miraa chewing than this study at $55.7 \%$ [26]. This possibly was also due to the same reason (miraa is cultivated in that area) and also may be due to the difference in the socio-demographic characteristic of the populations in the study areas.

Table1. Chewing of Miraa by Gender

\begin{tabular}{|c|c|c|c|}
\hline & Males & Females & Total \\
\hline Yes & $51.95 \%$ & $26.19 \%$ & $42.86 \%$ \\
\hline No & $48.05 \%$ & $73.81 \%$ & $57.14 \%$ \\
\hline Total & $64.70 \%$ & $35.30 \%$ & $100.00 \%$ \\
\hline
\end{tabular}

$\mathrm{N}=119$

The relationship between gender and miraa chewing was tested at the 0.05 level of significance. The chi-square value obtained is $7.362\left(\mathrm{X}^{2}=7.362\right)$ with 1 degree of freedom. The $\mathrm{p}$-value is $0.007(\mathrm{p}$ value $<0.05$ ) implying that there is a significant relationship between the two variables (gender and miraa chewing). Hence gender is a demographic determinant of miraa chewing amongst the youth in central division of Wajir East Sub County. Male are almost 2 times more likely to chew miraa than female.

This difference in miraa chewing between male and female would be explained by the common tendency of males to abuse substance compared to females. In miraa chewing communities, it appears there is greater cultural acceptance of males chewing of miraa compared to families .This opinion concurs with views expressed by the religious leaders during the key informants' interview. They explained that it was a cultural phenomenon that dates back hundreds of years; the society views negatively females who use miraa compared to male.

Table 2 below presents the distribution of the respondents based on their age bracket and the percentages of those who chew or do not chew miraa. Majority of the respondents were in the age bracket 18-21years (29.4\%) followed by the age bracket $22-25$ years $(26.1 \%)$. The age bracket of those from 33 up to 35 years had the least number of respondents (12.6\%). The age brackets 26-29 years and $30-33$ years constituted $15.1 \%$ and $16.8 \%$ of the respondents respectively. 
Abdikadir Sheikh Abdisalan et al.

Table2. Age and Miraa Chewing

\begin{tabular}{|c|c|c|c|c|c|c|c|}
\hline & & \multicolumn{5}{|c|}{ Respondent's Age } & \multirow{2}{*}{ Total } \\
\hline & & $18-21$ & $22-25$ & $26-29$ & $30-33$ & above 33 & \\
\hline \multirow{2}{*}{$\begin{array}{c}\text { Have you ever chewed } \\
\text { miraa? }\end{array}$} & Yes & $20.00 \%$ & $38.71 \%$ & $44.44 \%$ & $65.00 \%$ & $73.33 \%$ & $42.86 \%$ \\
\hline & No & $80.00 \%$ & $61.29 \%$ & $55.56 \%$ & $35.00 \%$ & $26.67 \%$ & $57.14 \%$ \\
\hline \multicolumn{2}{|l|}{ Total } & $29.41 \%$ & $26.05 \%$ & $15.13 \%$ & $16.81 \%$ & $12.61 \%$ & $100.0 \%$ \\
\hline
\end{tabular}

$\mathrm{N}_{=} 119$

Majority (73.3\%) of those who have chewed miraa are more likely to be found in the age bracket 3335 years, while majority ( $80 \%$ ) of those who have never chewed miraa are more likely to be found in the age bracket of 18-21.The reason why higher percentage of older youth (33-35 age bracket) reported to have chewed miraa compared to other age brackets is because in the Somali community miraa is chewed by adult men. The traditional/cultural elders interviewed unanimously reported that traditionally miraa used to be chewed exclusively by adults and elderly men, mainly for recreational purposes and after work. The increasing chewing of miraa by young people is an emerging phenomenon which the society does not fully approve. The reason why majority of those who reported not to have chewed miraa (80\%) fall in the lowest age bracket (18-21 years) would also be partly due to the stigma associated with young people chewing, hence some may not have been comfortable in admitting that they have ever chewed miraa.

The relationship between the dependent variable (miraa chewing) and the independent variable (age) was tested at the 0.05 level of significance. The chi-square value obtained is $17.396\left(\mathrm{X}^{2}=17.396\right)$ with 4 degrees of freedom. The $\mathrm{p}$-value is 0.002 ( $\mathrm{p}$-value $<0.05$ ) hence implying that there is a significant relationship between the two variables (age and miraa chewing), implying that age is a demographic factor that determines miraa chewing in the study area.

The mean age of those who chewed miraa was 17.2 years. The lowest age at which youth started miraa chewing was 9 years while the highest age was 25 years. A study in Uganda established that majority of miraa chewers were in the age bracket 16-25years [27]. A similar study among University students in Ethiopia revealed that the average age of miraa chewers was 21 years [28]. The differences in mean ages of miraa chewing in these two studies would be due to differences in the demographic characteristics' of the respondents.

This study has also revealed that there is difference in the prevalence of miraa chewing based on level of education, as shown in the Table 3. The category with highest percentage of miraa chewers was that of those with primary level education at $71.4 \%$. It was followed by those with no formal education at $54.2 \%$ and those with secondary education at $32.7 \%$. Those with tertiary/collage education had the least miraa chewers amongst them at $25 \%$, followed by those with university level education at $28.6 \%$. Therefore the respondent's level of education is a determinant of miraa chewing, as indicated by the statistically significant association between the two variables, tested at the 0.05 level of significance. The chi-square value obtained was $12.704\left(\mathrm{X}^{2}=12.704\right)$ with 4 degree of freedom. The p-value is 0.013 implying a significant relationship between level of education and miraa chewing ( $\mathrm{p}$-value $<0.05$ ).

Table3. Level of Education and Miraa Chewing.

\begin{tabular}{|c|c|c|c|c|c|c|c|}
\hline \multicolumn{2}{|c|}{} & \multicolumn{5}{|c|}{ Respondent's level of education } & \multirow{2}{*}{ Total } \\
\cline { 2 - 8 } & $\begin{array}{c}\text { No formal } \\
\text { education }\end{array}$ & $\begin{array}{c}\text { Primary } \\
\text { education }\end{array}$ & $\begin{array}{c}\text { Secondary } \\
\text { education }\end{array}$ & $\begin{array}{c}\text { Tertiary } \\
\text { /College } \\
\text { education }\end{array}$ & $\begin{array}{c}\text { University } \\
\text { education }\end{array}$ & \\
\hline $\begin{array}{c}\text { Have you } \\
\text { ever } \\
\text { chewed } \\
\text { miraa? }\end{array}$ & Yes & $54.17 \%$ & $71.43 \%$ & $32.73 \%$ & $25.00 \%$ & $28.57 \%$ & $42.86 \%$ \\
\cline { 2 - 8 } & No & $45.83 \%$ & $28.57 \%$ & $67.27 \%$ & $75.00 \%$ & $71.43 \%$ & $57.14 \%$ \\
\hline \multicolumn{2}{|c|}{ Total } & $20.17 \%$ & $17.65 \%$ & $46.22 \%$ & $10.08 \%$ & $5.88 \%$ & $100.0 \%$ \\
\hline
\end{tabular}

$\mathrm{N}=119$

Accordingly, those with no formal education or low education level are more likely to chew miraa than those with higher education level. The youth with no formal education or those whose highest 
level of education is primary school might have missed the opportunity to improve their socioeconomic status in the society due to their low level of education. The resultant stress has 'pushed them' to chew miraa. This opinion was supported by the respondents' themselves. "To relieve stress" was reported as the main reason for miraa chewing by (35.3\%) of the respondents. This view, was also further corroborated by all of the key informants interviewed (chiefs, education officers, public health, religious, councilors \& youth leaders).

The reasons for chewing miraa mentioned by the respondents are summarized in Table 4 below.

Table4. Reasons for Chewing Miraa

\begin{tabular}{|c|c|c|c|}
\hline & Males & Females & Total \\
\hline To release stress & $35.00 \%$ & $36.36 \%$ & $35.29 \%$ \\
\hline To pass/kill time & $25.00 \%$ & $45.45 \%$ & $29.41 \%$ \\
\hline To fit in the company of friends & $7.50 \%$ & $0.00 \%$ & $5.88 \%$ \\
\hline To work hard & $20.00 \%$ & $0.00 \%$ & $15.69 \%$ \\
\hline Curiosity & $10.00 \%$ & $18.18 \%$ & $11.76 \%$ \\
\hline Others & $2.50 \%$ & $0.00 \%$ & $1.96 \%$ \\
\hline Total & $78.43 \%$ & $21.57 \%$ & $100.00 \%$ \\
\hline
\end{tabular}

$\mathrm{N}=51$

Majority of the youth chew miraa either to "release stress" or to "pass/kill time" at $35.3 \%$ and $29.4 \%$ respectively, totaling to $64.7 \%$ of the miraa chewers. The other reasons given for chewing miraa are "to fit in the company of friends" (5.9\%), "to work hard" (15.7\%) and "curiosity" (11.8\%).

"To release stress" is a common factor in miraa use among both males (35\%) and females (36.4\%). The "stress" would be due to unemployment, underemployment or reduced life opportunities among the youth in the study area. From the information collected from the Key Informants, it also emerged that unemployment and inability to participate in economically beneficial activity is contributing factor in miraa use.

Females do not chew miraa in order to "work hard" unlike males where $20 \%$ reported that they chew miraa in order to "work hard". Hence it shows that there is difference in the nature of work done by males and females (gender roles) in the study area. However, females are almost two times (45.5\%) more likely to chew miraa in order to "pass/kill time" than males $(25 \%)$. This would be due to more idleness among the female population in the study area compared to males.

Similar reasons, "peer pressure" and "relieving stress" was also mentioned in another study [29]. Another study reported that miraa is chewed "to keep alert while reading" and for "relaxation with friends" [30]. Other reasons for chewing miraa reported in the literature are "to get concentration", "for religious prayers" "for enjoyment" and "to accompany or socialize" with family members [31], "to reduce fatigue" and "increase performance" [32, 33, 34].

\section{Conclusion}

Miraa chewing is both human resource and public health problem. The disastrous socio-economic and health consequences of the youth indulging in miraa chewing are enormous.

The objective of the study was to establish the demographic determinants of miraa chewing among the youth in Central division of Wajir East Sub County, Kenya. Age, gender and level of education were the demographic factors that were found to have had a statistically significant association with miraa chewing $(\mathrm{P}<0.05)$, hence would determine its use amongst the study population.

The findings of this study will to contribute to knowledge based formulation of realistic and appropriate preventive programs to help curb the problem of miraa chewing among the youth. The information that has been generated from this study would also enrich the existing body of knowledge, specifically on miraa consumption and generally on drugs and substance abuse.

\section{REFERENCES}

[1] NACADA. (2004). Youth in peril: alcohol and drug abuse in Kenya. Nairobi: Longman.

[2] Kerichio, B. (1994). Drug Abuse in Kenya, Nairobi, Uzima Press.

[3] Kalix, P., \& Braenden, O. (1985). Pharmacological aspects of the chewing of miraa leaves. Pharmacological Reviews Journal, 37, pp.149-164. 
[4] UNODC. (2004). Global drug trends. Newyork. United Nations.

[5] Murad, F. (1983). Social effects of miraa. In J. Mayberry, G. Morgan., \& E. Perkin. (eds.). Miraa-induced schizophreniform psychosis in UK. pp. 211-214. Madagascar: International Council on Alcohol and Addictions

[6] UNODC. (2004).Global drug trends. Newyork. United Nations.

[7] Giannini, A. J., Burge, H., Shaheen. J. M., \& Pace, W. A. (1986). Miraa: another drug of abuse? Journal of Psychoactive Drugs 18, pp.155-158.

[8] NACADA. (2004). Youth in peril: alcohol and drug abuse in Kenya. Nairobi: Longman.

[9] Mwenesi, H.A (1994). Drug abuse in Kenya: A national report. Nairobi: United Nations Drug Control Programme, Regional Office for East and Central Africa

[10] Mwai, J.N. (2001).The Drug abuse monster. Thika: Vallen Publishers.

[11] NACADA. (2004). Youth in peril: alcohol and drug abuse in Kenya. Nairobi: Longman

[12] Basheer, T. A. (1980). The use of miraa: a stimulant with regional distribution. In G. Edwards, \& A. Arif. (eds.), Drug problems in the Sociocultural Context; A basis for policies and programme Planning.( pp. 86-93.). Geneva: World Health Organization.

[13] Kennedy, J. G. (1987). The flower of paradise - the institutionalized use of Miraa in north Yemen. D. Reidel. Dordrecht.

[14] NACADA. (2004). Youth in peril: alcohol and drug abuse in Kenya. Nairobi: Longman

[15] NACADA. (2006). Frequently asked questions on drug and substance abuse, Nairobi: NACADA

[16] Basheer, T. A. (1980). The use of miraa: a stimulant with regional distribution. In G. Edwards, \& A. Arif. (eds.), Drug problems in the Sociocultural Context; A basis for policies and programme Planning.( pp. 86-93.). Geneva: World Health Organization.

[17] Kennedy, J. G. (1987). The flower of paradise - the institutionalized use of Miraa in north Yemen. D. Reidel. Dordrecht.

[18] Giannini, A. J., Burge, H., Shaheen. J. M., \& Pace, W. A. (1986). Miraa: another drug of abuse? Journal of Psychoactive Drugs 18, pp.155-158.

[19] Weir, S. (1985). Miraa in Yemen-consumption and social change. British Museums Publications: London.

[20] Elmi, A. S. (1983a). The chewing of miraa in Somalia. Journal of Ethnopharmacology, 8, pp.163-176.

[21] Luqman, W., \& Danowski, T. S. (1976). The use of miraa (Catha edulis) in Yemen; social and medical observations. In Journal of Internal Medicine, 85, 246249.

[22] NACADA. (2004). Youth in peril: alcohol and drug abuse in Kenya. Nairobi: Longman.

[23] WHO Expert Committee on Drug Dependence (1985). Twenty-second Report, World Health Organization Technical Report Series, No. 729. Geneva:WHO

[24] Aden, A., Odimba, E.O., Ndolo, U.M., \& Chundra, M.C. (2006). The socio-economic effects of khat chewing in Kenya. East African Medical Journal. 83(3).pp. 67-73.

[25] Adugna, F., Jira, C., \& Molla, T. (1991). Khat chewing among Agora school students, Agora south western Ethiopia. Ethiopia Medical Journal, 32(3), pp.161-6.

[26] Alem, A., Kebede, D., \& Kullgren, G. (1999). The prevalence and socio-demographic correlates of miaa chewing in Butajira, Ethiopia. In Acta Psychiatric Scandinavica Supplement, 1999;397(1): pp, 84-91.

[27] Ihunwo,A.O., Kayanja,F.I.,\& Amadi-ihunwo,U.B.(2004). Use and perception of psycho stimulant khat among three occupational groups in south western Uganda. East African Medical Journal.81(9): 468-472

[28] Zain, Z.A. (1988). Polydrug abuse among Ethiopian university students with particular reference to Miraa, In Harm Reduction Journal 91(2):1-70.

[29] Ageely, H.M. (2009). Health and Socioeconomic hazards associated with khat consumption. Journal of Family and Community Medicine. Vol.15, pp. 73-76.

[30] Yared, K. (2002).Cigarette smoking and khat chewing among college students in northwest Ethiopia. East African Medical Journal.79:274-278 
[31] Tesfaye, F., Byass, B., Wall, S., Berhane, Y., \& Bonita., R. (2006). Association of smoking and and khat(Catha eduslis) use with high blood pressure among adults in Addis Ababa, Ethiopia. Prev Chronic Dis. 5: 1-11

[32] Ayana,A.M., \& Mekonnen,Z (2004).Miraa chewing, socio-demographic disruption and its effects on academic performance on jima university students, Ethiopia. Ethiopian Medical Journal.42:125-136

[33] Zain, Z.A. (1988). Polydrug abuse among Ethiopian university students with particular reference to Miraa, In Harm Reduction Journal 91(2): 1-70

[34] Kebede,Y.(2002). Prevalence and risk factors of cigarette smoking and miraa chewing among college students in North West Ethiopia. The East African Medical Journal 79, pp.74- 91. 